\title{
PELESTARIAN RAWON NGULING SEBAGAI NILAI TAMBAH PADA PENGEMBANGAN WISATA KULINER TRADISIONAL INDONESIA
}

\author{
Sri Fajar Ayuningsih \\ Institut Ilmu Sosial dan Manajemen Stiami \\ fajarayu36@gmail.com
}

\begin{abstract}
Abstrak. Rawon adalah makanan khas dari Jawa Timur. Penampakan sup daging ini khas dengan kuah berwarna kehitaman karena memakai bumbu keluwak. Rumah Makan Rawon Nguling di Probolinggo termasuk salah satu tujuan wisata kuliner yang paling terkenal. Rumah makan ini telah ada sejak tahun 1942 dan kini telah memiliki 11 rumah makan waralaba di beberapa kota di Indonesia. Sebagai salah satu kekayaan kuliner tradisonal, Rawon Nguling patut dilestarikan. Untuk itu diperlukan suatu langkah pengembangan yang tepat dengan melalui pendekatan standarisasi bumbu Rawon Nguling dan teknik memasak yang lebih praktis yaitu pembekuan bumbu. Dari hasil penelitian, bumbu Rawon Nguling standar (bumbu Rawon Nguling-Fajar) yang dibekukan hingga selama 15 hari dalam skala penelitian, terbukti dapat dihasilkan bumbu Rawon Nguling dengan kualitas rasa, bau/flavor, dan warna yang tidak berbeda dari bumbu Rawon Nguling standar segar. Dalam bentuk bumbu yang dibekukan, maka bumbu Rawon Nguling menjadi lebih praktis, lebih tahan lama disimpan, dan memungkinkan untuk dilestarikan. Dari hasil analisa proksimat, Rawon Nguling merupakan makanan dengan kompisisi gizi yang lengkap, terutama sebagai pemenuhan kebutuhan protein hewani sebesar 52,2\% dari AKG. Selain itu, bumbu-bumbu dalam masakan rawon Nguling juga mengandung berbagai senyawa bioaktif yang baik untuk menjaga kesehatan, di antaranya antioksidan, antimikrobia, antidiabetes, antitumor, dan fungsi lainnya.
\end{abstract}

Kata kunci: Bumbu rawon, Rawon Nguling, makanan khas Jawa Timur, pelestarian kuliner tradisional.

Abstract.Rawon is a typical food from East Java. Appearance of this meat soup is typical with blackish-colored sauce for wearing kebwak spice. Rawon Nguling's restaurant in Probolinggo is one of the most famous culinary destinations. This restaurant has been around since 1942 and now has 11 franchised restaurants in several cities in Indonesia. As one of the traditional culinary wealth, Rawon Nguling is worth preserving. For that required a proper development step by using the standard approach of spice Rawon Nguling and cooking techniques that is more practical ie freezing spices. From the result of research, Rawon Nguling standard spice (Rawon Nguling-Fajar seasoning) frozen up to 15 days in research scale, proved to be able to produce spice Rawon Nguling with flavor, smell / flavor, and color that is not different from Rawon Nguling fresh standard. In the form of frozen spices, the Rawon Nguling spices become more practical, more durable stored, and allow to be preserved. From the results of proximate analysis, Rawon Nguling is a food with a complete nutritional composition, especially as the fulfillment of animal protein requirements of $52.2 \%$ of AKG. In addition, spices in Ngurah Rawon cuisine also contain a variety of bioactive compounds that are good for maintaining health, including antioxidants, antimicrobial, antidiabetic, antitumor, and other functions.

Keywords: Rawon Nguling, Rawon Nguling, East Java specialties, traditional culinary preservation.

\section{PENDAHULUAN}

Masakan lokal mencerminkan sejarah dan budaya suatu daerah dan dapat menjadi daya tarik bagi para wisatawan. Selain menyediakan makanan berkualitas baik bagi wisatawan, berbagai upaya harus dilakukan untuk mempromosikan hidangan unik daerah tujuan yang disukai wisatawan, setidaknya mencoba masakan lokal (Inskeep, 1991: 286). 
Sri Fajar Ayuningsih, Pelestarian Rawon Nguling Sebagai Nilai Tambah Pada Pengembangan ...

Salah satu daerah di Indonesia yang memiliki destinasi wisata kuliner yang potensial adalah Jawa Timur. Berbagai jenis makanan khas Jawa Timur selalu dicari oleh para wisatawan, di antaranya ialah rawon. Hampir di setiap kota wilayah Jawa Timur terdapat rumah makan atau restoran yang menyajikan rawon dengan resep dan cara penyajian yang khas. Seperti halnya rumah makan Rawon Nguling yang terletak di kampung Nguling, desa Tongas, Probolinggo. Rawon Nguling ini telah ada sejak tahun 1942 dan masih eksis hingga sekarang. Bahkan telah memiliki 11 waralaba yang tersebar di beberapa kota besar di Indonesia.

Secara umum, keistimewaan rawon adalah memiliki cita rasa gurih yang disukai, tampilannya unik dengan kuah hitam berkat penggunaan bumbu keluwak (Pangium edule). Dari segi nutrisi, rawon juga menyumbangkan asupan protein karena memakai bahan utama berupa daging sapi. Berbagai keunggulan rawon Nguling inilah yang membuatnya patut dilestarikan esksistensinya.

Sementara itu, upaya mengembangkan makanan tradisional Nusantara dihadapkan pada kendala antara lain sanitasi yang buruk, proses pengolahan yang cenderung tidak praktis, kurang memperhatikan gizi, lemahnya unsur teknologi, atau kendala budaya yang sering kali menghambat transfer pengetahuan tentang makanan tradisional itu sendiri.

Dari permasalahan tersebut, maka dapat digambarkan dalam problem tree berikut ini.

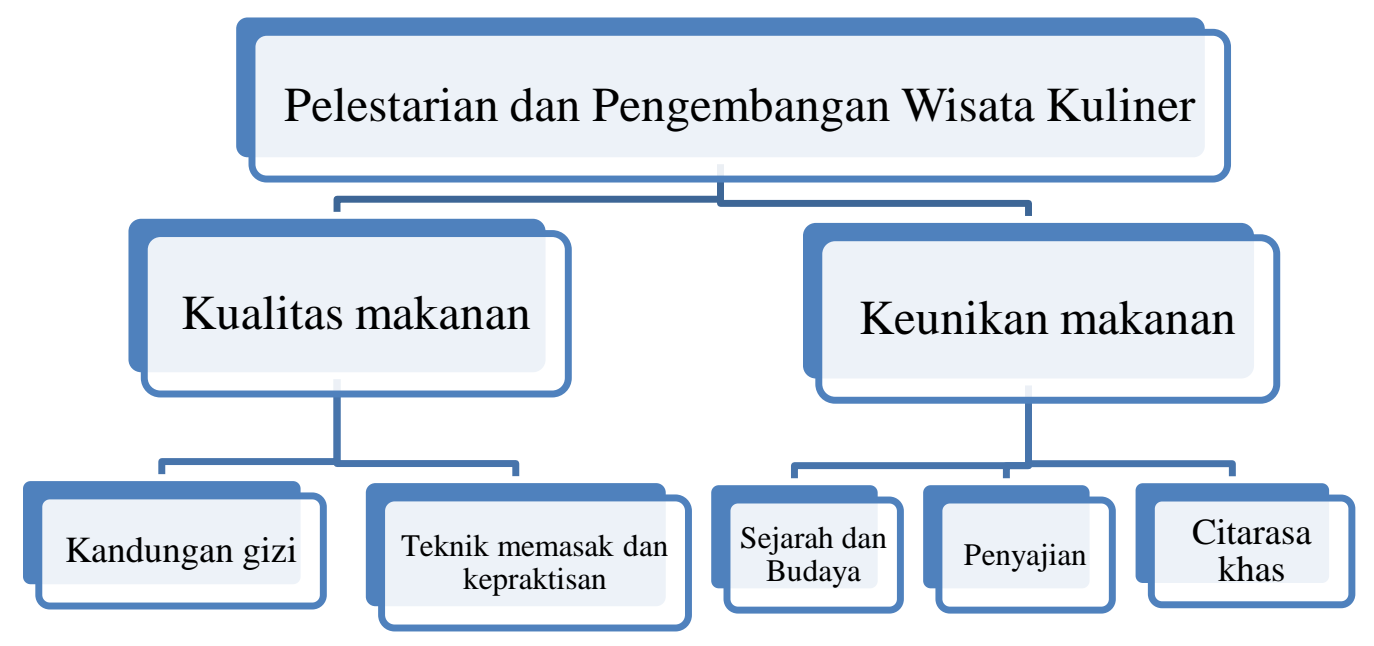

Gambar 1.1. Pohon masalah penelitian.

Tujuan yang hendak dicapai dengan melakukan penelitian ini berdasarkan permasalahan di atas adalah sebagai berikut:

1. Tujuan umum: Melestarikan dan mengangkat citra makanan atau kuliner tradisional Indonesia berdasarkan kajian dan analisis.

2. Tujuan khusus: Mengelaborasi definisi rawon, menyusun resep standar rawon sesuai obyek penelitian, melakukan uji proksimat pada rawon untuk membahas manfaat rawon. Memberikan tambahan informasi tentang makanan tradisional Indonesia dalam rangka upaya pelestarian dan meningkatkan

masyarakat.

pemahaman

\section{TINJAUAN PUSTAKA}

\section{Pelestarian Wisata Kuliner Tradisional}

Dalam perspektif antropologi, makanan bukanlah sesuatu yang dipandang semata-mata berhubungan dengan aspek fisiologis dan biologis manusia, melainkan secara menyeluruh terserap dalam suatu sistem budaya makanan. (Rohendi, 2001). Makanan tradisional adalah makanan yang telah membudaya di kalangan masyarakat Indonesia, serta telah ada sejak nenek moyang 


\section{ISSN 1411-0830}

suku nusantara (Muhilal,1995). Menurut Winarno (1993), makanan tradisional adalah makanan yang pekat dengan tradisi setempat.

Istilah 'kuliner' berkaitan erat dengan konsumsi makanan sehari-hari dan merupakan sebuah gaya hidup yang tidak dapat dipisahkan dari kehidupan manusia, karena sehari-hari setiap orang memerlukan makanan. Dalam kamus Webster (1913) kuliner atau culinary adalah "Relating to the kitchen, or to the art of cookery; used in kitchens; as, a culinary vessel; the culinary art". Pengenalan akan kultur tersebut akan membangkitkan kesan mendalam dan penghargaan dari wisatawan, sehingga akan mengajaknya untuk kembali berkunjung.

Dari perspektif antropologi, kuliner tidak terlepas dari pola konsumsi dan kapitalisme. Kegiatan makan seringkali dianggap sebagai kegiatan pemenuhan kebutuhan dasar semata, padahal dari sudut kajian antropologi budaya, kegiatan makan merupakan suatu bagian dari tujuh unsur kebudayaan. Setiap kebudayaan memiliki kekhasan tersendiri dalam kegiatan makan, mulai dari menyiapkan bahan makanan, proses memasak, mengemas, hingga proses memakannya. Mengingat pentingnya nilainilai budaya, pelestarian kuliner tradisional harus selalu diupayakan. Juga perlu diteruskan kepada generasi muda sebagai pemangku budaya.

\section{Rawon dalam Sejarah}

Salah satu kekayaan kuliner yang patut dilestarikan adalah rawon. Rawon merupakan masakan khas Jawa Timur yang sangat populer dan banyak dijajakan di warung makan, restoran, hingga dijadikan menu hotel berbintang di Indonesia. Bahkan, rawon masuk dalam daftar 40 makanan Indonesia terlezat versi CNNGo, sebuah layanan streaming yang memberikan berita terbaru dan terhangat melalui perangkat Apple TV. (Helabumi, 2013).

Pakar boga, Bondan Winarno, juga merekomendasikan rumah makan rawon Nguling yang terletak di wilayah perbatasan antara Pasuruan dan Probolinggo sebagai salah satu rawon dari empat rumah makan rawon terenak se-Jawa Timur. Destinasi wisata kuliner kota Probolinggo ini telah ada sejak tahun 1942 dan saat ini usahanya meningkat pesat dengan cara mengembang sistem waralaba (www.travel.tempo.com, 2008). Hal ini dapat dijadikan sebagai tolok ukur bahwa rumah makan rawon Nguling disukai khalayak dan mendapat tempat khusus di hati penggemar kuliner tradisional.

Pengetahuan atau informasi mengenai sejarah rawon itu sendiri sangat sulit ditemukan dikarenakan minimnya data, catatan, atau hasil penelitian yang ilmiah tentang rawon. Meski demikian, di beberapa kitab sastra Jawa Baru pada abad ke-18 dapat ditemukan informasi mengenai rawon dan keluwak sebagai bumbu penting dalam rawon, meski sangat minim.

Keluwak sebagai beberapa kali disebut dalam Serat Centhini yaitu salah satu naskah sastra Jawa yang yang ditulis pada tahun 1735 Jawa dengan sengkalan atau angka tahun berbunyi tata guna swareng nata (tahun 1811 Masehi). Serat Centhini ditulis oleh raja bekerjasama dengan para pujangga kraton. Salah satu raja yang dikenal pandai menulis dalam hal sastra Jawa adalah Paku Buwana V. Adapun salah satu hasil tulisan beliau yang menjadi karya besar adalah Serat Centhini tersebut. Serat Centhini dikenal juga sebagai buku ensiklopedia budaya Jawa. (Susilantini, 2014).

Menurut laporan penelitian Pusat Kajian Makanan Tradisional, UGM (1997), di dalam kitab Kakawin Bhomakaya (81.37) tercatat bahasan mengenai rawon, yaitu rarawwan (sayur rawon), enak ikay rarawwan amarěg-marěgi (rawon enak dan mengenyangkan). Bahasan mengenai resep rawon juga muncul dalam Serat Wulangan Olah-olah Warna-warni, semacam catatan atau buku masak koleksi Istana Mangkunegaran Surakarta yang dicetak pada tahun 1926 (Haryono dan Kayati, 1998). Buku masak ini terdiri dari beberapa bagian atau bab, yaitu Olah-olahan Cara Walandi (olahan atau masakan cara Belanda), Olaholahan Cara Jawi (olahan atau masakan cara Jawa), Dedhaharan Cara Walandi (kue dan dessert cara Belanda), Asinan Sarta Acar Warna-Warni (asinan dan acar warna-warni), 
Sri Fajar Ayuningsih, Pelestarian Rawon Nguling Sebagai Nilai Tambah Pada Pengembangan ...

Pandamelipun Sosis Warna-warni (pembuatan sosis warna-warni).

Dalam buku ini, resep rawon masuk dalam bab Olah-olahan Cara Jawi atau masakan Jawa, nomor 173. Jika diterjemahkan dalam bahasa Indonesia, artinya adalah sebagai berikut. Rawon. Rajangan atau irisan tipis bawang merah 10, rajangan atau irisan tipis bawang putih 1 , ketumbar 1 sendok kecil, rajangan atau irisan kunyit 6, trasi 1 sendok kecil, lengkuas 2 iris, ditumbuk hingga lembut lalu digoreng dengan minyak kelapa. Setelah memotong-motong daging 2, lalu direbus. Jika sudah keluar kaldunya, rebusan daging tadi ditambah bumbu yang sudah digoreng serta diberi asem jawa bakaran 1 mata. Irisan cabai merah 6 , keluwak 2, kemiri 1, daun jeruk purut 3 lembar, daun salam 2 lembar, serai secukupnya, lalu dimasak bersama rebusan daging hingga matang.

\section{Bumbu dan Bahan dalam Resep Rawon, serta Fungsinya}

Bumbu dan rempah rempah-rempah di Indonesia umumnya digunakan sebagai bahan penyedap (flavoring) untuk makanan dan minuman. Berjalan dengan waktu, herbal dan rempah-rempah bukan saja digunakan untuk meningkatkan citarasa, namun juga digunakan sebagai bahan untuk menunda atau mencegah ketengikan dan kerusakan makanan. (Antara dan Wartini).

Selain keluwak sebagai bumbu wajib, terdapat berbagai bumbu yang digunakan dalam pengolahan atau pemasakan rawon. Menurut Murdiati (2013), penggunaan bumbu ini sangat beragam, baik dari jenis maupun karakteristiknya. Bumbu juga berkontribusi sebagai pembentuk cita rasa masakan atau hidangan, juga memiliki fungsi tertentu.
a. Bawang merah (Allium cepa L.).
b. Bawang putih (Allium sativum).
c. Cabai merah besar (Capsicum annum L.).
d. Daun bawang (Allium porum L.).
e. Jahe (Zingiber officinale Roscoe).
f. Kunyit (Curcuma domestica Val. atau Curcuma longa Auct.).
g. Kencur (Kampferia galangal L.).
h. Lengkuas (Languas galangal atau Alpinia galangal L.).

i. Kemiri (Aleurites moluccana).

j. Ketumbar (Coriandrum sativum).

k. Jintan (Cuminum cyminum).

1. Merica (Piper nigrum).

m. Serai (Cymbopogon citrates atau Andropogon schoenanthus).

n. Daun jeruk purut (Cirus hyxtrix D.C).

o. Daun salam (Eugenia polyantha. Wight).

p. Terasi matang.

q. Gula pasir.

r. Garam.

s. Minyak goreng.

t. Air.

\section{Keluwak Sebagai Pembentuk Karakter Rawon}

Keluwak (Pangium edule Reinw) termasuk bumbu khusus untuk masakan tertentu. Berasal dari biji pohon keluwak atau kepayang atau pucung, yang digunakan adalah daging bagian dalamnya yang berwarna cokelat kehitaman. Memberikan warna hitam, aroma dan rasa khas pada masakan. Namun menurut Burkil (1935) dalam Timbul (2001:11) menyatakan bahwa perebusan biji kluwak selama sejam akan mencegah terbentuknya asam sianida, karena pemanasan akan menonaktifkan enzim ginokirdase yang berperan terhadap produksi asam sianida dengan menghidrolisis ginokardise.

Buah keluwak mengandung asam sianida sehingga memerlukan penanganan tertentu sebelum dikonsumsi. Asam sianida dalam buah ini biasanya dihilangkan dengan cara menyimpan buah yang telah dimasak selama 10-14 hari hingga kulit buahnya membusuk. Kemudian, biji keluwak dipisahkan, dicuci, dan direbus. Biji yang telah direbus kemudian ditimbun/dikubur di dalam tanah selama 40 hari, seteleh itu biji dikeluarkan dan dicuci. Kemungkinan adanya fermentasi selama ditimbun mengakibatkan daging di dalam biji keluwak mengalami 'pembusukan' alamiah sehingga warna berubah menjadi cokelat kehitaman dan berlemak (Murdijati-Gardjito, 2013).

Keluwak mengandung senyawa antioksidan dan golongan flavonoid. Senyawa antioksidan yang berfungsi sebagai antikanker dalam biji picung antara lain: vitamin $\mathrm{C}$, ion 
besi, dan B karoten. Sedangkan golongan flavonoid biji picung yang memiliki aktivitas antibakteri yakni asam sianida, asam hidnokarpat, asam khaulmograt, asam gorlat dan tanin. Khusus senyawa asam sianida dan tanin, kedua senyawa inilah yang mampu memberikan efek pengawetan terhadap ikan (Koswara, 2009).

\section{Daging Sapi}

Daging sapi adalah bahan utama dalam pembuatan masakan rawon. Berdasarkan SNI 3932:2008 tentang mutu karkas dan daging sapi disebutkan bahwa yang dimaksud dengan daging sapi adalah bagian otot skeletal dari karkas sapi yang aman, layak dan lazim dikonsumsi oleh manusia, dapat berupa daging segar, daging dingin, atau daging beku (SNI 3932:2008, butir 3.2).

Daging segar adalah daging yang belum diolah dan atau tidak ditambahkan dengan bahan apapun (butir 3.3), daging segar dingin adalah daging yang mengalami proses pendinginan setelah penyembelihan sehingga temperatur bagian dalam daging antara $0^{\circ} \mathrm{C}$ dan $4^{\circ} \mathrm{C}$ (butir 3.4), sedangkan daging beku adalah daging segar yang sudah mengalami proses pembekuan di dalam blast frezeer dengan temperatur internal minimun $-16^{\circ} \mathrm{C}$.

Pembagian potongan daging sapi ini mengikuti aturan tertentu dan masing-masing potongan mempunyai ciri khas dan kualitas tersendiri dalam pengolahan (Murdiati dan Amalia, 2003).

a. Blade (punuk).

b. Chuck (paha depan).

c. Cube roll (lemusir).

d. Sirloin (has luar).

e. Tenderloin (has dalam).

f. Topside/round (penutup).

g. Rump (tanjung).

h. Silver (gandik).

i. Inside/knuckle (kelapa).

j. Shank (sengkel).

k. Flank (samcan).

1. Rib meat (iga).

m. Brisket (sandung lamur). Menurut Anggorodi

dinyatakan bahwa komposisi kimia daging sapi terdiri dari $66.6 \%$ air, $20.2 \%$ protein, $12.3 \%$ lemak dan $0.9 \%$ abu. Secara umum komposisi kimia daging terdiri atas $70 \%$ air, $20 \%$ protein. $9 \%$ lemak dan $1 \%$ abu. Jumlah ini akan berubah jika hewan digemukkan, yang mengakibatkan pengurangan persentase air dan protein serta terjadi peningkatan kadar lemak (Romans. dkk. 1994). Daging sebagai sumber protein hewani mengandung 19\% protein, $5 \%$ lemak $70 \%$ air $3,5 \%$ zat —zat non protein, mineral dan bahan lainnya (Arbele, dkk. 2001). Menurut Lawrie (1991) komposisi daging mendekati $75 \%$ air, $18 \%$ protein, $3.5 \%$ lemak dan $3.5 \%$ zat-zat non protein yang dapat larut. Menurut Kartono, 2014, AKG berdasarkan Permenkes nomor 75 tahun 2013 hasil WNPG (Widyakarya Nasional Pangan dan Gizi) ke-X tahun 2012, rerata kecukupan energi dan protein nasional adalah $2150 \mathrm{kkal} \& 57$ gr per orang per hari, dengan proporsi anjuran protein hewani sebesar $25 \%$.

\section{Pengawetan Pangan Suhu Rendah (Pembekuan)}

Pembekuan dapat mempertahankan rasa dan nilai gizi bahan pangan yang lebih baik daripada metoda lain, karena pengawetan dengan suhu rendah (pembekuan) dapat menghambat aktivitas mikroba mencegah terjadinya reaksi kimia dan aktivitas enzim yang dapat merusak kandungan gizi bahan pangan. Walaupun pembekuan dapat mereduksi jumlah mikroba yang sangat nyata tetapi tidak dapat mensterilkan makanan dari mikroba (Frazier, 1977).

Menurut Tambunan (1999), pembekuan berarti pemindahan panas dari bahan yang disertai dengan perubahan fase dari cair ke padat, dan merupakan salah satu proses pengawetan yang umum dilakukan untuk penanganan bahan pangan. Dengan pembekuan, makanan akan lebih awet karena aktivitas mikroba terhenti dan aktivitas enzim juga terhambat. Dibandingkan dengan pengalengan, teknologi pembekuan lebih dapat mempertahankan kandungan nutrisi pada bahan pangan apabila dilakukan dengan benar (Desrosier, 1988).

\section{Pengujian Sensori}

Evaluasi sensori atau organoleptik adalah ilmu pengetahuan yang menggunakan 
Sri Fajar Ayuningsih, Pelestarian Rawon Nguling Sebagai Nilai Tambah Pada Pengembangan ...

indera manusia untuk mengukur tekstur, penampakan, aroma dan flavor produk pangan. Penerimaan konsumen terhadap suatu produk diawali dengan penilaiannya terhadap penampakan, flavor dan tekstur. Pendekatan dengan penilaian organoleptik dianggap paling praktis lebih murah biayanya (Kartika dkk, 1987)

Pada prinsipnya terdapat 3 jenis uji organoleptik, yaitu uji pembedaan (discriminative test), uji deskripsi (descriptive test) dan uji afektif (affective test). (Lawless dan Heymann, 2010). Menurut Lawless dan Heymann, 2010, pengujian deskriminatif (pembedaan) terdiri atas dua jenis, yaitu uji difference test (uji pembedaan) yang dimaksudkan untuk melihat secara statistik adanya perbedaan diantara contoh dan sensitifity test, yang mengukur kemampuan panelis untuk mendeteksi suatu sifat sensori. Diantara uji pembedaan adalah uji perbandingan pasangan (paired comparison test) di mana para panelis diminta untuk menyatakan apakah ada perbedaan antara dua contoh yang disajikan; dan uji duo-trio (duotrio test) dimana ada 3 jenis contoh (dua sama, satu berbeda) disajikan dan para penelis diminta untuk memilih contoh yang sama dengan standar. Uji lainnya adalah uji segitiga (triangle test), yang sama seperti uji duo-trio tetapi tidak ada standar yang telah ditentukan dan panelis harus memilih satu produk yang berbada. Berikutnya adalah uji rangking (ranking test) yang meminta para panelis untuk merangking sampel-sampel berkode sesuai urutannya untuk suatu sifat sensori tertentu.

\section{Analisa Proksimat}

Pertama kali dikembangkan di Weende Experiment Station Jerman, oleh Hennenburg dan Stokmann. Oleh karena analisis ini sering dikenal dengan nama analisis Weende. Analisis Proksimat menggolongkan komponen yang ada pada bahan pangan berdasarkan komposisi kimia dan fungsinya, yaitu: air (moisture), abu (ash), protein kasar (crude protein), dan bahan ekstrak tanpa nitrogen (nitrogen free ekstrak). Analisis proksimat ini menggolongkan vitamin berdasarkan kelarutannya. Vitamin yang larut dalam air dimasukkan ke dalam fraksi air, sedangkan yang larut dalam lemak dimasukkan ke dalam lemak kasar.

Kelebihan analisis ini antara lain kebanyakan laboratorium menggunakan analisis ini, alat mahal dan canggih kurang dibutuhkan, menghasilkan analisis secara garis besar, dapat menghitung TDN (total digestible nutrient) berdasarkan hasil analisi proksimat (Suparjo:2010)

\section{Rerangka Konsepsi}

Rawon sebagai makanan tradisional khas Jawa Timur memiliki potensi dan peluang untuk menjadi salah satu daya tarik wisata kuliner di Indonesia. Rawon memiliki penampilan khas, yaitu berwarna hitam karena memakai bumbu keluwak, juga memiliki citarasa gurih yang disukai orang. Ada beberapa cara yang dapat dilakukan untuk melestarikan dan mengembangkan potensi rawon yang dapat ditunjukkan melalui rerangka konsepsi seperti di bawah ini.

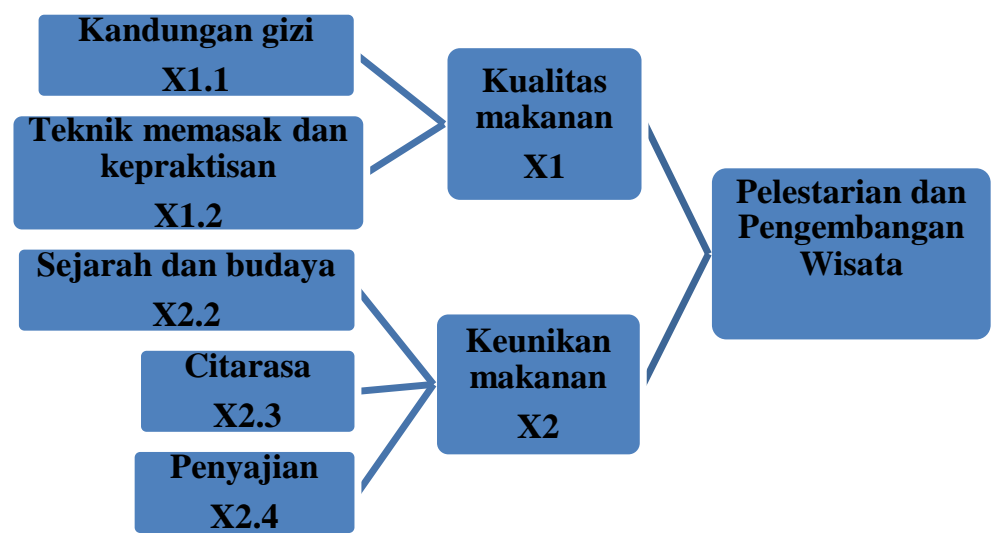

Gambar. 2.6. Rerangka Konsepsi 


\section{Hipotesis}

Berdasarkan kajian teori yang telah dikemukakan, maka dapat dibuat suatu hipotesis sebagai berikut.

H1 diterima jika hasil menunjukkan tidak berbeda nyata dengan $\mathrm{HO}$ dengan tingkat signifikansi > 0.05, di mana:

H1 adalah bumbu rawon Nguling (versi Fajar) dengan perlakuan pembekuan

H0 adalah bumbu rawon Nguling (versi Fajar) yang dibuat langsung (kontrol)

\section{METODE PENELITIAN}

\section{Waktu dan Tempat Penelitian}

Dalam penelitian ini, obyek penelitiannya adalah bumbu Rawon Nguling - Probolinggo yang dibuat di Jakarta berdasarkan penuturan $\mathrm{H}$. Rofiq (pengelola rumah makan Rawon Nguling). Penelitian ini dimulai dari bulan Mei 2014 hingga Juli 2015 dengan lokasi penelitian di Jawa Timur dan Jakarta. Untuk data yang berkaitan dengan resep, sejarah, dan budaya tentang rawon dilakukan di wilayah Jawa Timur, yaitu Surabaya, Malang, Pasuruan, dan Probolinggo. Untuk uji sensori Tes Pembeda (Difference Test) dilakukan di kampus STP Trisakti, kampus Akpindo, dan di lingkungan warga Pondok Bambu, Jakarta. Sedangkan, untuk pengujian proksimat dilaksanakan di Laboratorium Balai Besar Industri Agro (BBIA), di Bogor.

\section{Bahan dan Alat Penelitian}

Bahan utama yang digunakan dalam pembuatan Rawon Nguling ini ialah daging sapi bagian sampil, sandung lamur dan sengkel, air, bumbu rawon, dan minyak goreng untuk menumis bumbu. Bumbu rawon itu sendiri terdiri dari bawang merah, bawang putih, cabai merah besar, keluwak, kemiri, jahe, kunyit, kencur, ketumbar, jintan, merica, daun bawang, serai, daun jeruk purut, daun salam, lengkuas, dan terasi matang). Bahan dasar ini diperoleh dari pasar tradisional, yaitu Pasar Besar Probolinggo, di Probolinggo, Jawa Timur, tempat yang rutin menjadi penyedia rempah-rempah yang digunakan dalam pembuatan rawon Nguling. Dengan membeli bahan-bahan dari sumber yang sama, diharapkan bumbu rawon standar yang dihasilkan dapat memberikan cita rasa, warna, dan aroma yang tidak berbeda dari rawon Nguling. Bahan lain yang digunakan adalah gula pasir merek Gulaku, dan garam merek Dolphin.

Alat yang digunakan dalam pembuatan bumbu Rawon Nguling ini terdiri dari: wadah plastik, pisau, talenan, sendok ukur, sutil, gelas, timbangan digital, kompor gas, panci presto, blender, chopper, wajan, dan freezer. Sedangkan, alat untuk uji sensori meliputi: mangkuk beling kecil (cawan) untuk wadah sampel, sendok kecil, gelas ukur, nampan, kompor portable, panci, sendok sayur.

\section{Penelitian Pendahuluan}

Penelitian pendahuluan ini diawali dengan melakukan wawancara dengan narasumber yang memiliki kompetensi (pemilik rumah makan Rawon Nguling Probolinggo), budayawan/sejarahwan, antropolog, lembaga pendidikan, pelaku bisnis kuiner, ahli kuliner, serta instansi pemerintah terkait: Disbudpar provinsi Jawa Timur, Disbudpar Pemkot dan Pemda Probolinggo, dan lainnya). Selain itu, melakukan observasi terhadap Rawon Nguling (melakukan pengamatan terhadap bahan baku, cara pembuatan, penyajian, hingga cara menikmati rawon), dan melakukan studi pustaka yang bersumber dari buku-buku yang menunjang isi penulisan, naskah/buku kuna, dan artikel media massa (termasuk sosial media) untuk mengetahui sejarah dan budaya rawon serta data lainnya yang menunjang isi penelitian.

\section{Penelitian Tahap 1: Pembuatan Bumbu Rawon Nguling Standar}

Pembuatan bumbu rawon Nguling standar dilakukan dengan pendekatan:

a. jenis bumbu yang digunakan adalah barang yang sama dibeli di tempat yang sama 
Sri Fajar Ayuningsih, Pelestarian Rawon Nguling Sebagai Nilai Tambah Pada Pengembangan ...

b. mengkuantifikasi semua bumbu sesuai penuturan pemilik rumah makan rawon Nguling

c. pembuatan bumbu dengan variasi urutan bumbu yang dihaluskan.

Hasil dari penelitian tahap ini adalah bumbu rawon Nguling standar, atau yang selanjutnya disebut bumbu rawon Nguling (versi Fajar). Tujuannya adalah memasak rawon Nguling versi Fajar untuk mendapatkan versi standar yang digunakan sebagai pembanding dalam pengujian membuat rawon Nguling (versi Fajar) menggunakan bumbu rawon Nguling (versi Fajar) hasil penelitian tahap 1 dengan diuji citarasanya melalui uji pembedaan dengan rawon Nguling asli sampai didapatkan citarasa yang dinilai sama. Hasil tahap 1 adalah bumbu rawon Nguling (versi Fajar) dan hidangan rawon Nguling (versi Fajar) yang kemudian diuji.

Tahapan pembuatan rawon NgulingFajar dijelaskan dalam gambar 3.1.

\section{Gambar 3.1. Diagram alir pembuatan Rawon Nguling-Fajar}

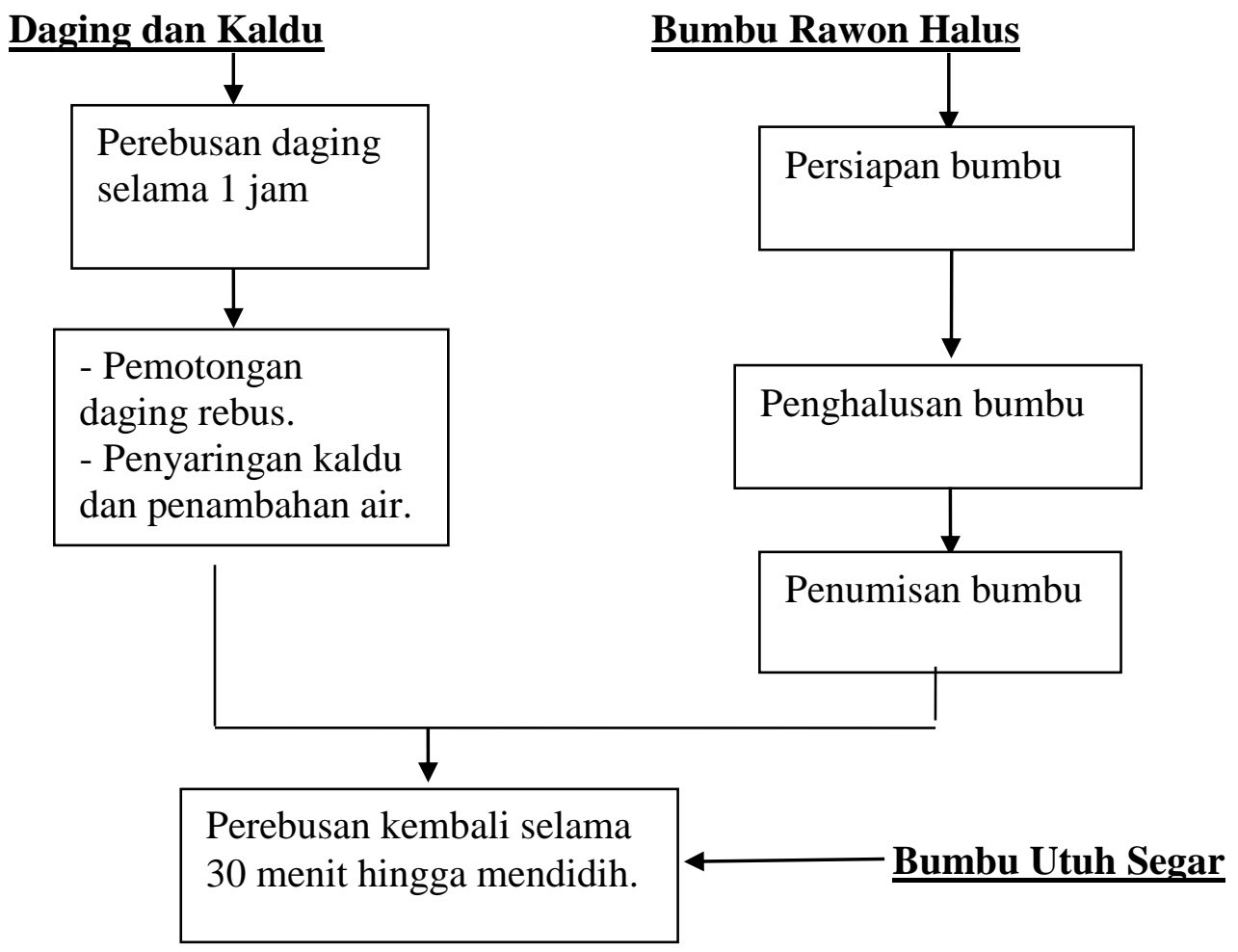

\section{Penelitian Tahap 2: Pembekuan Bumbu}

a. Pembuatan sampel bumbu rawon Nguling (versi Fajar) hasil tahap 1 sebanyak sebanyak dibutuhkan 10 kali resep bumbu rawon (untuk 12 porsi). Bumbu rawon Nguling (versi Fajar) yang sudah dihaluskan ditumis hingga matang dan kering, selanjutnya didiamkan hingga mencapai suhu ruang, lalu dikemas dalam kemasan kantung plastik sebanyak 10 kantung.

b. Melakukan penyimpanan sampel bumbu rawon Nguling (versi Fajar) pada suhu beku selama waktu yang ditentukan.

\section{Penelitian Tahap 3: Uji Sensori}

a. Melakukan pengujian rasa, aroma, warna bumbu Rawon Nguling-Fajar yang disimpan beku. Pada hari ke 3, 6, 9, 12, 15 dilakukan pengambilan 2 sampel bumbu untuk memasak rawon Nguling (versi Fajar) yang dimasak menjadi 24 porsi. Di waktu yang sama, dimasak juga rawon Nguling (versi Fajar) standar sebagai pembanding.

b. Melakukan uji inderawi (sensori), di mana sampel bumbu rawon Nguling (versi Fajar) 
yang disimpan dibandingkan dengan bumbu yang baru dibuat.

\section{Dilakukan pengujian pembedaan antara sampel rawon Nguling dengan rawon Nguling segar oleh panelis}

Uji organoleptik yang digunakan dalam penelitian ini adalah Uji Pembedaan atau Difference Test, yaitu Paired Comparison Test, untuk mengetahui secara statistik apakah ada perbedaan di antara 2 sampel yang disajikan. Sampel yang diujikan yaitu bumbu rawon Nguling (versi Fajar) dengan perlakuan simpan beku dibandingkan dengan kontrol, yaitu bumbu fresh yang dibuat langsung. Pengamatan akan dilakukan setiap 3 hari sekali selama 15 hari. Lamanya waktu pengamatan ditentukan dengan pertimbangan bahwa pembuatan bumbu rawon Nguling (versi Fajar) setiap 12 hari sekali dinilai cukup meringankan pekerjaan dalam skala rumah tangga maupun industri rumahan, juga lebih praktis. Sedangkan, pengamatan lanjutan hinga hari ke-15 dimaksudkan untuk penjaminan mutu produk yang aman hingga hari ke-15.

Pengujian ini menggunakan panelis semi terlatih sebanyak 20 orang. Parameter yang diujikan meliputi rasa, aroma, dan warna. Jika antar kedua sampel SAMA, maka nilainya 1 . Jika antar kedua sampel BEDA, maka nilainya 0 .

\section{Analisis Proksimat}

Analisa proksimat ini ditujukan untuk mengetahui kandungan komponen tertentu dalam 1 porsi penyajian rawon Nguling (versi Fajar), yang meliputi protein, lemak, karbohidrat, serat, dan energi. Sampel yang diuji meliputi: 1 porsi rawon Nguling (versi Fajar) standar (terdiri dari $200 \mathrm{ml}$ kuah rawon dan 50 gram daging rawon) dan 1 porsi rawon Nguling (versi Fajar) komplet (terdiri dari 200 $\mathrm{ml}$ kuah rawon, 50 gram daging rawon, $1 / 2$ butir telur asin seberat 30 gram, 1 potong tempe goreng seberat 35 gram, 15 gram taoge pendek mentah, sambal terasi sebesar 7,5 gram).

\section{Analisa kadar air (AOAC, 2005)}

Analisa kadar air dilakukan dengan menggunakan metode oven. Prinsip kerjanya ialah menguapkan molekul air $(\mathrm{H} 2 \mathrm{O})$ bebas yang ada dalam sampel. Setelah diuapkan, sampel ditimbang sampai diperoleh bobot konstan yang diasumsikan semua air yang terkandung dalam sampel sudah diuapkan. Selisih bobot sebelum dan sesudah pengeringan merupakan banyaknya air yang diuapkan.

\section{Analisa kadar abu (AOAC, 2005)}

Analisa kadar abu dilakukan menggunakan metode oven. Prinsip kerjanya adalah pembakaran atau pengabuan bahanbahan organik yang diuraikan menjadi air (H2O) dan karbondioksida (CO3), tetapi zat anorganik tidak terbakar. Zat anorganik ini disebut abu.

\section{Analisa kadar lemak (AOAC, 2005)}

Analisa kadar lemak dilakukan dengan metode sokhlet. Prinsip kerjanya adalah lemak yang terdapat dalam sampel diekstraksi dengan menggunakan pelarut lemak non polar.

\section{Analisa kadar protein (AOAC, 2005)}

Analisa kadar protein dilakukan dengan metode kjeldahl. Prinsip kerjanya adalah oksidasi bahan-bahan berkarbon dan konversi nitrogen menjadi amonia oleh asam sulfat, selanjutnya amonia bereaksi dengan kelebihan asam membentuk amonium sulfat. Amonium sulfat yang terbentuk diuraikan dan larutan dijadikan basa dengan $\mathrm{NaOH}$. Amonia yang diuapkan akan diikat dengan asam borat. Nitrogen yang terkandung dalam larutan ditentukan jumlahnya dengan titrasi menggunakan larutan baku asam.

\section{Analisa kadar karbohidrat (Winarno, 1997) \\ Penentuan kadar karbohidrat menggunakan by difference dengan rumus sebagai berikut: \% karbohidrat $=100 \%$ - (kadar air + kadar protein + kadar abu + kadar lemak) $\%$}


Sri Fajar Ayuningsih, Pelestarian Rawon Nguling Sebagai Nilai Tambah Pada Pengembangan ...

\section{Kadar Lemak (Metode Soxhlet), SNI 01- 2891-1992}

Sampel yang telah dihaluskan ditimbang sebanyak 2 gr, lalu dimasukkan ke dalam selongsong kertas yang dialasi dengan kapas. Selongsong kertas berisi contoh sampel tersebut di sumbat dengan kapas dikeringkan dalam oven pada suhu tidak lebih dari $80^{\circ} \mathrm{C}$ selama 1 jam, kemudian masukkan ke dalam alat soxhlet yang telah diberi labu lemak yang berisi batu didih yang telah dikeringkan dan telah diketahui bobotnya, kemudian ekstrak lemak dengan heksan atau pelarut lemak lainnya selama 6 jam, lalu heksan disuling dan keringkan ekstrak lemak dalam oven pengering pada suhu $105^{\circ} \mathrm{C}$, setelah itu didinginkan dalam eksikator lalu ditimbang, perlakuan ini diulangi hingga tercapai bobot tetap.

\section{Kadar Protein (Metode Semimikro Kjeldhal), SNI 01-2891-1992.}

Cuplikan sebanyak $0,51 \mathrm{~g}$ ditimbang, kemudian dimasukkan ke dalam labu kjeldhal $100 \mathrm{ml}$. Cuplikan diberi tambahan $2 \mathrm{~g}$ campuran selen dan $25 \mathrm{ml} \mathrm{H} 2 \mathrm{SO} 4$ pekat, kemudian dipanaskan di atas pemanas listrik sampai mendidih dan larutan menjadi jernih kehijau-hijauan (sekitar 2 jam pada suhu $420^{\circ} \mathrm{C}$ ). Sampel dibiarkan dingin, kemudian encerkan dan dimasukkan ke dalam labu ukur $100 \mathrm{ml}$, lalu ditambahkan sampai tanda garis (tera). Larutan sebanyak $5 \mathrm{ml}$ dipipet dan masukkan ke dalam alat penyuling, kemudian ditambahkan $5 \mathrm{ml} \mathrm{NaOH} 30 \%$ dan beberapa tetes indikator PP, lalu disuling selama 10 menit, sebagai penampung digunakan $10 \mathrm{ml}$ larutan asam borat $2 \%$ yang telah dicampur indikator. Ujung pendingin dibilas dengan air suling, lalu dititar dengan HCL 0,01 N. \%

\section{Analisa Kadar Serat Pangan}

Analisa kadar serat pangan metode enzimatik (Asp et al. 1993). Serat pangan (serat makanan) adalah bagian dari makanan yang tidak dapat dihidrolisis oleh enzimenzim pencernaan, meliputi selulosa, hemiselulosa, lignin, pentosan, gum dan senyawa pektik. Analisis serat pangan meliputi homogenisasi dan liofilisasi.

\section{Analisis Data}

Analisa data dilakukan dengan menggunakan acuan tabel uji pembedaan untuk uji sensori dari paket statistik MINITAB dengan signifikansi $5 \%$ atau tingkat kepercayaan sebesar $95 \%$.

\section{HASIL DAN PEMBAHASAN}

\section{Hasil Penelitian Pendahuluan}

Rawon adalah sajian tradisional khas dari daerah Jawa Timur yang disukai oleh kalangan luas, berupa masakan daging berkuah dengan penggunaan bumbu rempah yang lengkap. Penampakannya unik dengan warna cokelat kehitaman dan bercita rasa gurih dari hasil penambahan bumbu utamanya, yaitu keluwak (Emmawati, 1998).Penelitian ini difokuskan pada rumah makan rawon Nguling yang terdapat di wilayah perbatasan daerah Tongas-Nguling, Probolinggo di provinsi Jawa Timur. Dari hasil wawancara pada medio Mei 2014 dengan budayawan dan sejarahwan yang tinggal di Probolinggo, Harsito, disebutkan bahwa di kalangan masyarakat setempat dengan tingkat ekonomi menengah ke atas terdapat tradisi menyajikan rawon sebagai suguhan dalam acara pesta pernikahan atau perhelatan lain. Rawon dinilai sebagai sajian mewah yang cita rasanya disukai orang dan dan dianggap sebagai masakan yang tidak cepat basi sehingga memudahkan penanganannya bagi orang yang bekerja di dapur hajatan. Pemahamanan hal ini selaras dengan hasil penelitian yang menyatakan bahwa rempah-rempah penyusun bumbu rawon, terutama keluwak, cabai merah, dan kunyit yang bersifat antimikrobia dan antioksidan, serta berfungsi sebagai pengawet alami (Fardiaz, 1998).

Saat ini, penyajian rawon sebagai lauk menu sehari hari telah menjadi hal yang umum di masyarakat. Selain dimasak dalam skala rumah tangga, rawon juga banyak dijual di warung makan hingga restoran di wilayah kota Probolinggo. Salah satu penjual rawon yang paling terkenal adalah rumah makan rawon Nguling (Kompas.com, 2013) 
Rumah makan rawon Nguling telah ada sejak Desember 1942, terletak di pinggir jalan raya Tongas, dulu dikenal sebagai Jalan Raya Pos (De Grote Postweg) Anyer Panarukan yang dibangun oleh Gubernur Jenderal Herman Willem Daendels pada masa penjajahan Belanda. Menurut penuturan $\mathrm{H}$. Rofiq Ali, generasi ketiga penerus bisnis rumah makan Rawon Nguling, rumah makan milik pasangan suami istri Mbah Karyodirejo dan Mbah Marni ini awalnya dinamakan Warung Lumayan yang menyajikan rawon dengan memakai alas daun pisang atau pincuk. Kekhasan penyajiannya membuat warung makan ini dikenal dengan sebutan rawon pincuk.

Dikatakan oleh H. Rofiq, selanjutnya pengelolaan warung makan rawong Nguling dipegang oleh generasi kedua, yaitu $\mathrm{H}$. Dahlan beserta istrinya, Karsimuk. Usaha warung makan ini makin maju dan berkembang, maka pada tahun 1995 namanya dipatenkan menjadi Rumah Makan Rawon Nguling. Untuk menjaga mutu makanan yang disajikan di rumah makan tersebut, hingga saat ini penggunaan resep peninggalan kakeknenek pendahulunya masih terus diterapkan.

Secara umum, resep rawon Nguling hampir sama dengan resep rawon yang sudah dikenal masyarakat luas. Perbedaannya terletak komposisi atau takaran bumbu dan teknik pengolahan bahan-bahannya. Kekhasan bumbu rawon Nguling ini ialah daun bawangnya tidak ditambahkan setelah rawon matang, melainkan ikut dihaluskan bersama bumbu lainnya. Ini yang membuat cita rasanya makin gurih. Untuk mempertahankan mutu, semua bahan-bahan dan bumbu yang dipakai dalam pembuatan rawon Nguling diperoleh dari pemasok langganan dan pasar tradisional di wilayah Lumajang dan Probolinggo.

Keistimewaan itulah yang membuat rumah makan rawon Nguling mampu berkembang pesat dan sejak tahun 2008 berwaralaba di 11 kota besar di Indonesia. Agar mutu sajian rawon Nguling selalu sama, maka teknis waralaba yang dilakukan yaitu dengan cara melatih pekerja di dapur yang bertugas khusus memasak rawon dan menyediakan sejumlah bumbu rawon siap olah yang dibuat di dapur pusat di Probolinggo dalam keadaan beku. Bumbu rawon beku ini dikemas dalam kemasan plastik masing-masing seberat $1 \mathrm{~kg}$ untuk memasak kurang lebih 35 porsi rawon dan dikirim ke restoran waralaba di kota lain secara berkala sesuai dengan pesanan.

\section{Pembuatan Produk Bumbu Standar}

Hal yang utama dalam pembuatan produk adalah selalu mendapatkan kualitas yang sama setiap kali dimasak. Untuk itu dibutuhkan adanya resep standar. Ini untuk memastikan produk yang dibuat akan sama setiap kali dibuat dan disajikan, siapapun yang memasaknya. Selain itu, juga untuk mengontrol kuantitas, yaitu untuk menyatakan berapa banyak (kuantitas) bahan yang dipakai, sehingga setiap bahan itu ditimbang. Yang berikutnya menyatakan untuk berapa banyak (porsi) dan berapa banyak pula perporsinya (Gisslen, 2011).

Yang dimaksud dengan resep standar ialah gabungan dari beberapa instruksi yang menjelaskan cara-cara tertentu dalam mempersiapkan suatu hidangan, dengan kata lain adalah merupakan resep yang dikembangkan oleh suatu dapur untuk digunakan oleh juru masaknya dengan menggunakan peralatan yang ada. Kegunaan resep standar adalah untuk mengontrol kualitas (Gisslen, 2011).

Tahapan kegiatan pembuatan bumbu rawon Nguling adalah sebagai berikut:

\section{Persiapan Bahan Bumbu}

Pada umumnya, bumbu rawon terdiri dari 2 kelompok, yaitu bumbu yang dihaluskan dan bumbu utuh segar. Demikian pula halnya dengan bumbu rawon Nguling. Menurut H. Rofiq Ali, bumbu yang dihaluskan terdiri dari: keluwak, daun bawang, cabai merah, bawang merah, bawang putih, kemiri, ketumbar, merica, jintan, jahe kunyit, kencur, terasi matang, garam, dan gula pasir. Sedangkan bumbu segar utuh terdiri dari: daun salam, lengkuas, serai, dan daun jeruk.

\section{Penghalusan \\ Penumisan Bumbu}


Sri Fajar Ayuningsih, Pelestarian Rawon Nguling Sebagai Nilai Tambah Pada Pengembangan ...

Bumbu rawon Nguling (versi Fajar) yang sudah dihaluskan, selanjutnya ditumis selama 15 menit hingga uap airnya berkurang, lalu ditambahkan minyak goreng. Proses penumisan dilanjutkan kembali hingga bumbu benar-benar matang, beraroma harum, dan kering. Tandanya, terdapat minyak yang terpisah di bagian pinggiran bumbu. Setelah ditumis, bumbu mengalami penyusutan kadar air sekitar $14-15 \%$.

\section{Perebusan Daging dan Perawonan}

Setelah tahapan persiapan bumbu hingga penumisan bumbu selesai, langkah selanjutnya adalah perebusan daging dan perawonan. Yang dimaksud dengan perawonan adalah proses pencampuran bumbu rawon ke dalam rebusan daging dan pememasakan hingga bumbu rawon meresap.

Rawon Nguling menggunakan komposisi daging sapi yang khas untuk pembuatan kaldu yang pekat, yaitu campuran antara daging sampil, sandung lamur, dan sengkel. Pemilihan penggunaan daging ini tepat dan sesuai dengan SNI 013932-1995 mengenai Mutu Karkas dan Daging Sapi, di mana disebutkan ketiga jenis daging tersebut memang diperuntukkan dalam pembuatan sop dan hidangan berkuah lainnya. Daging sandung lamur dan sengkel memiliki kandungan lemak yang lebih tinggi, sedangkan daging sampil memiliki kolagen lebih banyak.

Daging untuk rawon ini direbus dengan air dingin hingga mendidih pada suhu $100^{\circ} \mathrm{C}$ selama 1 jam hingga empuk. Selanjutnya ditambahkan bumbu rawon halus dan rempah segar (lengkuas, daun salam, daun jeruk, dan serai). Proses perawonan ini dilakukan sedikitnya hingga 1 jam untuk memberi kesempatan bumbu meresap ke dalam daging. Lazimnya, rawon diinapkan semalaman dan dihidangkan pada keesokan harinya agar bumbu benar-benar meresap ke dalam daging dan hal ini akan menambah kenikmatan rasa rawon.

Tabel 4.1. Komposisi Bahan Bumbu Rawon Nguling-Fajar untuk 12 Porsi

\begin{tabular}{|l|c|c|}
\hline Bahan Bumbu & $\begin{array}{l}\text { Berat Bersih } \\
\text { Dalam Gram }\end{array}$ & $\begin{array}{l}\text { Dalam Presentase } \\
\%\end{array}$ \\
\hline Keluwak & 50 & 14,28 \\
\hline Daun bawang & 50 & 14,28 \\
\hline Cabai merah & 50 & 14,28 \\
\hline Bawang merah & 50 & 14,28 \\
\hline Bawang putih & 15 & 4,28 \\
\hline Kemiri & 10 & 2,85 \\
\hline Ketumbar & 6 & 1,71 \\
\hline Merica butiran & 5 & 1,42 \\
\hline Jintan & 1 & 0,28 \\
\hline Jahe & 10 & 2,85 \\
\hline Kunyit & 10 & 2,85 \\
\hline Kencur & 6 & 1,71 \\
\hline Daun salam & 4 & 1,14 \\
\hline Lengkuas & 15 & 4,28 \\
\hline Serai & 30 & 8,57 \\
\hline Daun jeruk purut & 3 & 0,85 \\
\hline Terasi matang & 5 & 1,42 \\
\hline Garam & 20 & 5,71 \\
\hline Gula Pasir & 10 & 2,85 \\
\hline TOTAL & 350 & 100 \\
\hline
\end{tabular}

Komposisi bahan bumbu rawon Nguling yang dibuat di Jakarta berdasarkan penuturan H. Rofiq (pengelola rumah makan Rawon Nguling) dapat dilihat pada Tabel 4.1. 


\section{Pembekuan Bumbu}

Produk bumbu rawon Nguling (versi Fajar) yang sudah ditumis, didiamkan beberapa saat hingga mencapai suhu ruang. Setelah itu, bumbu dikemas dalam kemasan plastik, kemudian disimpan pada bagian freezer di dalam lemari es pada suhu antara $2^{\circ} \mathrm{C}$ hingga suhu $-10^{\circ} \mathrm{C}$, di mana sebagian besar air yang ada di dalam produk (90\%95\%) membeku. Pembekuan bumbu rawon ini bertujuan untuk menjaga mutu dan memperpanjang umur simpannya. Pada kondisi beku pertumbuhan mikroba dapat dihambat. Untuk menjaga agar produk tetap beku, maka produk beku harus disimpan pada suhu di bawah titik bekunya, termasuk selama distribusi.

\section{Karakteristik Organoleptik Bumbu}

Sebelum dilakukan pengujian organoleptik, bumbu rawon Nguling (versi Fajar) beku dilelehkan (thawing) terlebih dahulu hingga mencapai suhu ruang. Proses thawing dilakukan dengan cara tidak terlalu besar, agar proses thawing berlangsung cepat (Syamsir, 2010). Selanjutnya, bumbu rawon direbus dengan air hingga mendidih, lalu ditambahkan bumbu segar utuh (daun salam, serai, lengkuas, dan daun jeruk). Selanjutnya rebusan bumbu rawon dibiarkan mendidih selama 30 menit untuk memberikan waktu untuk mengeluarkan aroma rempah-rempah. Sampel ini kemudian diujikan dalam kondisi panas.

Hasil Uji Pembedaan Paired Comparison Test pada bumbu rawon Nguling (versi Fajar) beku dengan parameter rasa, aroma/flavor, dan warna dapat dilihat pada Tabel. 4.1. Pada saat pengujian, para panelis diminta menilai apakah terdapat perbedaan antara bumbu rawon Nguling (versi Fajar) segar (dibuat langsung) sebagai kontrol dengan bumbu rawon Nguling (versi Fajar) yang diberi perlakuan penyimpanan beku. Pengujian dilakukan setiap tiga hari sekali, yaitu setelah bumbu rawon Nguling (versi Fajar) disimpan beku pada hari ke-3, ke-6, ke9, ke-12, dan ke-15.

\section{Rasa}

Definisi rasa atau cita rasa adalah persepsi biologis seperti sensasi yang dihasilkan oleh bahan yang masuk ke dalam mulut, dan yang kedua, cita rasa adalah karakter atau sifat bahan yang menghasilkan sensasi. Cita rasa terutama dirasakan oleh reseptor aroma dalam hidung dan reseptor rasa dalam mulut (Fisher dan Scott, 1997).

Tabel 4.2. Hasil Uji Pembedaan dengan Parameter Rasa

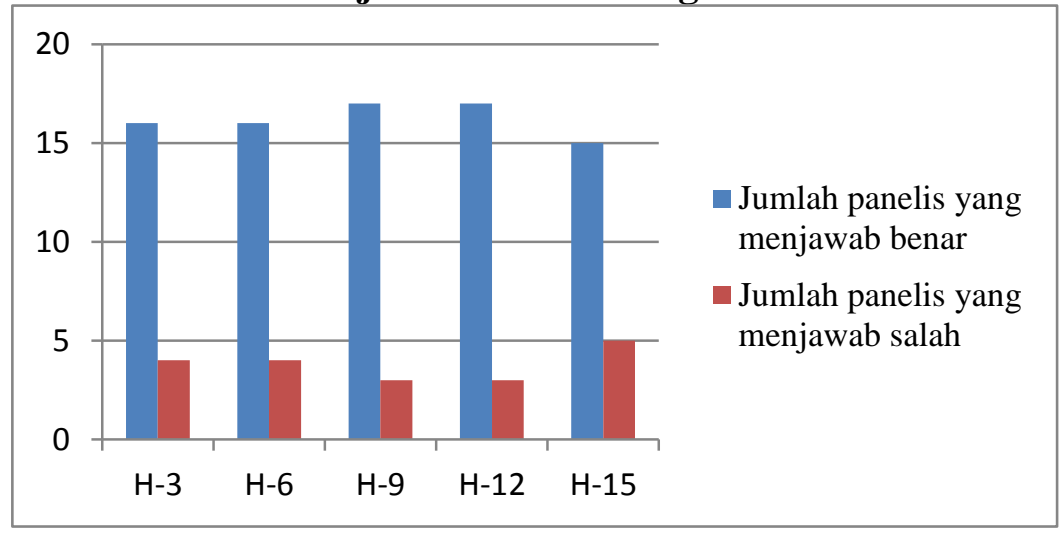

Keterangan:

H-3 = pengamatan lama penyimpanan bumbu beku rawon pada hari ke-3

H-6 = pengamatan lama penyimpanan bumbu beku rawon pada hari ke-6

$\mathrm{H}-9$ = pengamatan lama penyimpanan bumbu beku rawon pada hari ke-9

$\mathrm{H}-12$ = pengamatan lama penyimpanan bumbu beku rawon pada hari ke-12

$\mathrm{H}-15$ = pengamatan lama penyimpanan bumbu beku rawon pada hari ke-15 
Sri Fajar Ayuningsih, Pelestarian Rawon Nguling Sebagai Nilai Tambah Pada Pengembangan ...

Berdasarkan hasil pengujian pada Tabel 4.2. menunjukkan bahwa hasil Uji Pembedaan Berpasangan (Paired Comparison Test) terhadap bumbu rawon Nguling (versi Fajar) beku dan kontrol dengan parameter rasa di mana jumlah panelis yang menjawab benar rata-rata di atas nilai 15. Artinya, rasa antara bumbu rawon Nguling (versi Fajar) yang dibekukan dinilai tidak berbeda nyata dengan kontrol.

\section{Warna}

Warna khas pada bumbu rawon Nguling (versi Fajar) yaitu cokelat merah kehitaman ini banyak dipengaruhi oleh pemakaian bahan bumbu utamanya, terutama keluwak.

Tabel 4.3. Hasil Uji Pembedaan dengan Parameter Warna

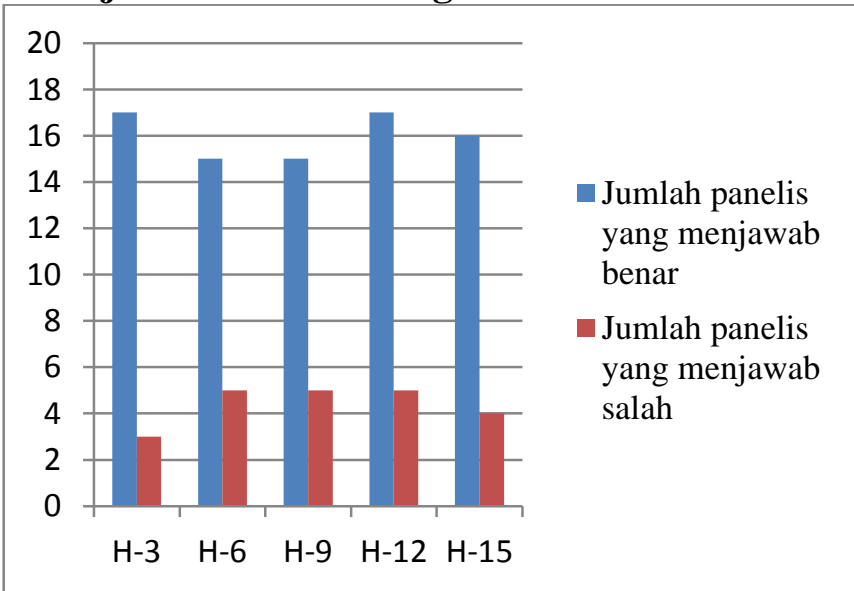

Keterangan:

H-3 = pengamatan lama penyimpanan bumbu rawon beku pada hari ke-3

H-6 = pengamatan lama penyimpanan bumbu rawon beku pada hari ke-6

H-9 = pengamatan lama bumbu rawon penyimpanan beku pada hari ke-9

$\mathrm{H}-12$ = pengamatan lama penyimpanan bumbu rawon beku pada hari ke-12

$\mathrm{H}-15$ = pengamatan lama penyimpanan bumbu rawon beku pada hari ke-15

Tabel 4.3. menunjukkan bahwa hasil Uji Pembedaan Berpasangan (Paired Comparison Test) terhadap bumbu rawon Nguling (versi Fajar) beku dan kontrol dengan parameter warna yaitu jumlah panelis yang menjawab benar rata-rata di atas nilai 15. Artinya, warna antara bumbu rawon Nguling (versi Fajar) yang dibekukan dinilai tidak berbeda nyata dengan kontrol.

\section{Aroma/flavor}

Aroma atau flavor khas pada bumbu rawon Nguling (versi Fajar) terbentuk karena adanya senyawa volatil dan minyak atsiri yang terkandung dalam bahan bumbu, di antaranya daun jeruk, daun salam, serai, dan jahe (Emmawati, 1998). Tabel 4.4. menunjukkan bahwa hasil Uji Pembedaan Berpasangan (Paired Comparison Test) terhadap bumbu rawon Nguling (versi Fajar) beku dan kontrol dengan parameter aroma yaitu jumlah panelis yang menjawab benar rata-rata di atas nilai 15 . Artinya, aroma antara bumbu rawon Nguling (versi Fajar) yang dibekukan dinilai tidak berbeda nyata dengan kontrol.

Tabel 4.4. Hasil Uji Pembedaan dengan Parameter Aroma/flavor 


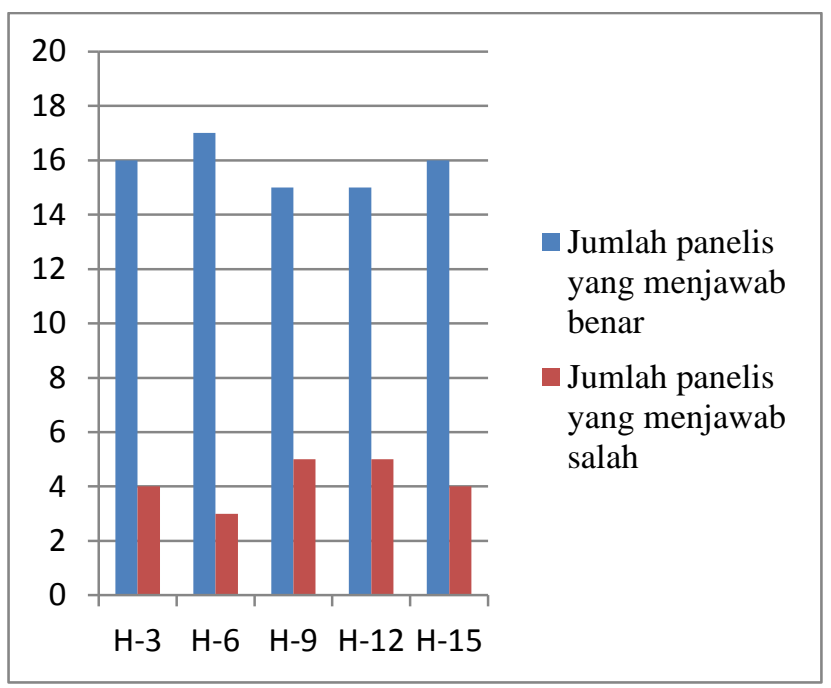

Keterangan:

H-3 = pengamatan lama penyimpanan bumbu beku rawon pada hari ke-3 H-6 = pengamatan lama penyimpanan bumbu beku rawon pada hari ke-6 H-9 = pengamatan lama penyimpanan bumbu beku rawon pada hari ke-9 H-12 = pengamatan lama penyimpanan bumbu beku rawon pada hari ke-12 $\mathrm{H}-15$ = pengamatan lama penyimpanan bumbu beku rawon pada hari ke-15

\section{Hasil Analisis Proksimat dan Serat Pangan} Di dalam penelitian ini, yang dimaksud dengan penyajian rawon Nguling (versi Fajar) standar ialah penyajian rawon yang terdiri dari $200 \mathrm{ml}$ kuah rawon dan 50 gr daging rawon. Sedangkan, yang dimaksud dengan penyajian rawon Nguling (versi Fajar) komplit ialah, penyajian rawon standar dengan tambahan pelengkap berupa setengah butir telur asin seberat 30 gr, satu potong tempe goreng seberat 35 gr, 15 gr taoge pendek mentah, dan sambal terasi seberat 7,5 gr.

Hasil analisis proksimat yang meliputi kadar air, kadar abu, kadar protein kadar lemak total, kadar karbohidrat total (by difference) dan energi, serta kadar serat dapat dilihat pada Tabel 4.5.

Tabel 4.5. Hasil Analisis Proksimat dan Serat Pangan

\begin{tabular}{|c|c|c|c|}
\hline \multirow[b]{2}{*}{ Parameter } & \multirow[b]{2}{*}{ Satuan } & \multicolumn{2}{|l|}{ Sampel } \\
\hline & & $\begin{array}{l}\text { Rawon Standar } \\
(250 \text { gr/porsi) }\end{array}$ & $\begin{array}{l}\text { Rawon Komplet } \\
(337,5 \text { gr/porsi) }\end{array}$ \\
\hline Air & $\%$ & 88,8 & 80,3 \\
\hline Abu & $\%$ & 0,56 & 1,06 \\
\hline Protein $(\mathrm{N} \times 6,25)$ & $\%$ & 7,28 & 8,58 \\
\hline Lemak & $\%$ & 2,04 & 6,99 \\
\hline Karbohidrat & $\%$ & 1,32 & $\mathbf{3 , 0 7}$ \\
\hline Energi & Kal/100gr & 53 & 110 \\
\hline Serat pangan & $\%$ & 0,48 & 1,6 \\
\hline
\end{tabular}


Dari hasil pengujian sifat kimia rawon Nguling (versi Fajar) diketahui bahwa kadar protein, kadar lemak, karbohidrat, energi, dan serat pangan dari rawon Nguling (versi Fajar) komplet per 100 gr bahan lebih besar dibandingkan dengan rawon Nguling (versi Fajar) standar. Namun untuk kadar air dan kadar abu rawon standar lebih kecil dibandingkan dengan rawon Nguling komplet.

\section{Kadar Air}

Sesuai dengan data dalam Tabel 4.5. kadar air pada kedua sampel cukup tinggi, yaitu rawon Nguling (versi Fajar) standar sebesar $88,8 \%$ dan rawon Nguling (versi Fajar) komplet sebesar 80,3\%. Hal ini dikarenakan rawon termasuk dalam jenis masakan sup dengan komposisi penyajian di mana porsi kuah lebih banyak dibandingkan isi berupa daging atau sayuran. Jika disajikan sebagai hidangan pembuka, seporsinya adalah 200 hingga $250 \mathrm{ml}$, sedangkan jika sebagai hidangan utama yaitu 300 hingga $350 \mathrm{ml}$ (Gisslen, 2011).

\section{Kadar Abu}

Berdasarkan Tabel 4.5. diketahui bahwa nilai kadar abu pada rawon Nguling (versi Fajar) standar yaitu $0,5 \%$ atau 1,25 gr per porsi dan pada rawon Nguling (versi Fajar) komplet yaitu $1,06 \%$ atau 3,15 gr per porsi. Di dalam tubuh unsur mineral ini berfungsi sebagai zat pembangun dan pengatur (Winarno 1992).

\section{Protein}

Tabel 4.5. menunjukkan bahwa kadar protein rawon Nguling (versi Fajar) komplet lebih tinggi yaitu $8,85 \%$, dibandingkan dengan rawon Nguling (versi Fajar) standar yaitu $7,28 \%$. Nilai energi yang disumbangkan dengan konversi 1 gr protein adalah $4 \mathrm{kal}$ adalah untuk rawon Nguling (versi Fajar) standar yaitu 29,1 kal per 100 gr produk atau 72,8 kal per porsi. Sedangkan pada rawon Nguling (versi Fajar) komplet yaitu 35,4 kal per 100 gr produk atau 119,5 kal per porsi.

Jumlah kebutuhan protein harian yang harus dikonsumsi adalah sebanyak $0,57 \mathrm{gr} / \mathrm{kg}$ berat badan laki-laki dewasa atau $0,54 \mathrm{~g} / \mathrm{kg}$ berat badan wanita dewasa. Jumlah tersebut sudah cukup untuk memenuhi keperluan menjaga keseimbangan nitrogen dalam tubuh, dengan syarat protein yang dikonsumsi mempunyai mutu tinggi (Winarno, 1992). Setiap porsi rawon Nguling (versi Fajar) standar mengandung 250 gr x $7,28 \%$ protein $=18,2 \mathrm{gr}$ protein sehingga memenuhi nilai AKG untuk protein sebesar 18,2/57 x 100\% = $31,9 \%$. Sedangkan, setiap rawon Nguling (versi Fajar) komplet mengandung 337,5 gr x $8,85 \%=29,8 \%$ protein sehingga memenuhi nilai AKG untuk protein sebesar 29,8/57 x $100 \%=52,2 \%$.

\section{Lemak}

Hasil analisis proksimat pada Tabel 4.5. menunjukkan kadar lemak pada rawon Nguling (versi Fajar) standar sebesar 2,04\% dan nilai energi yang disumbangkan dengan konversi 1 gr lemak adalah 9 kal yaitu 18,36 kal per 100 gr produk atau 45,9 kal per porsi. Setiap porsi rawon Nguling(versi Fajar) standar mengandung 5,1 gr lemak. Jumlah lemak yang dibutuhkan setiap hari berdasarkan diet 2150 kalori adalah sebanyak 60 gr sehingga pemenuhan nilai AKG untuk lemak per sajian yaitu 5,1/60 x 100\% $=13 \%$.

Sedangkan untuk rawon Nguling (versi Fajar) komplet kadar lemaknya sebesar $6,99 \%$. dan nilai energi yang disumbangkan yaitu sebesar $62,9 \mathrm{kal}$ per 100 gr produk atau 212,2 kal per porsi. Setiap porsi rawon Nguling komplet mengandung 6,99 gr lemak dan pemenuhan nilai AKG untuk lemak per sajian yaitu $6,99 / 60 \times 100 \%=39,3 \%$.

\section{Karbohidrat}

Kadar karbohidrat dihitung dengan metode by difference yaitu dengan mengurangi $100 \%$ dengan persentase kadar air, abu, protein, dan lemak (Apriyantono et al. 1989) sehingga didapatkan nilai kadar karbohidrat sebesar $1,32 \%$ untuk rawon Nguling standar dan 3,07\% untuk rawon Nguling komplet.

Nilai energi yang disumbangkan rawon Nguling (versi Fajar) standar dengan konversi 1 gr karbohidrat adalah 4 kal yaitu 5,28 kal per 100 gr produk atau 13,2 kal per porsi. Setiap porsinya mengandung $23,3 \mathrm{gr}$ karbohidrat, ini telah memenuhi nilai $\mathrm{AKG}$ 
untuk karbohidrat sebesar 7,16\%. Sementara, nilai energi yang tersedia dalam rawon Nguling (versi Fajar) komplet yaitu sebesar 12,3 kal per 100 gr produk atau 41,4 kal per porsi dan telah memenuhi $12,7 \%$ dari nilai AKG karbohidrat per porsi.

\section{Serat Pangan}

Perbedaan kadar serat pada kedua sampel bumbu Rawon Nguling (versi Fajar) dikarenakan adanya tambahan sebagian serat dari taoge mentah yang disajikan sebagai pelengkap rawon komplet. Kadar serat yang terkandung dalam 100 gr taoge yaitu sebesar 1,1 gr (Persagi, 2009).

\section{Manfaat Senyawa Bioaktif dalam Bumbu Rawon}

Dapat dikatakan bahwa bumbu rawon Nguling (versi Fajar) sangat lengkap. Hampir semua bumbu yang ada di dapur Indonesia dipakai. Rempah-rempah dimanfaatkan daunnya (segar atau kering), batang, kulit maupun umbi (rimpang) sebagai penyedap makanan dan minuman. Potensi bahan bumbu dan rempah-rempah yang terkandung dalam resep ini tidak hanya meningkatkan citarasa makanan, namun juga dapat berfungsi untuk kesehatan.

Di dalam bumbu dan rempah-rempah terdapat senyawa-senyawa bioaktif yang berfungsi sebagai antimikrobia, antioksidan, antidiabetes, antitumor, dan fungsi lainnya yang sangat bermanfaat untuk menjaga kesehatan. Untuk itu, selain digunakan di dapur sebagai bumbu masak, bahan-bahan ini juga banyak dikembangkan untuk keperluan pengobatan karena dipercaya tidak mempunyai efek samping yang berbahaya. Minyak atsirinya dapat digunakan untuk mengendalikan pertumbuhan mikrobia di dalam makanan. Salah satu contohnya adalah Alicin, yang merupakan senyawa aktif dari homogenat hancuran bawang putih, mempunyai berbagai aktivitas antimikrı

(Antara dan Wartini).

\section{SIMPULAN DAN SARAN}

\section{Simpulan}

Hasil penelitian menunjukkan bahwa upaya pelestarian rawon Nguling memungkinkan untuk dilakukan. Sebab, dengan menggunakan teknologi pembekuan, diperoleh bumbu rawon Nguling dengan kualitas cita rasa yang sama, baik dari aspek rasa, warna, dan aroma atau flavornya. Teknik pembekuan bumbu rawon Nguling ini dinilai lebih praktis diterapkan dalam skala rumah tangga dibandingkan jika harus membuat bumbu setiap kali memasak. Untuk skala yang lebih besar, bumbu rawon Nguling beku ini juga dapat diaplikasikan dalam bisnis kuliner dengan sistem waralaba di berbagai kota di Indonesia sebagai salah satu upaya pengembangan wisata kuliner tradisional Indonesia. Untuk menjaga agar mutu bumbu rawon beku tetap terjaga, produk beku haruslah disimpan pada suhu titik bekunya, termasuk selama distribusi.

Selain itu, dari evaluasi hasil analisa proksimat menunjukkan bahwa rawon Nguling merupakan sajian yang bergizi. Di dalam satu porsi penyajian rawon Nguling komplet menyediakan sumber protein hewani yang baik dan sejumlah senyawa bioaktif di dalam bumbu rawon yang bermanfaat dalam menjaga kesehatan.

\section{Saran}

Berdasarkan hasil penelitian yang telah dilakukan, terbuka peluang untuk melakukan penelitian lanjutan mengenai:

1. optimasi pengemasan dan distribusi bumbu rawon Nguling yang dibekukan

2. pembuatan rawon Nguling (Versi Fajar) dalam bentuk resep sehat rendah lemak, karena saat ini masyarakat mulai peduli terhadap aspek kesehatan

3. kajian tentang sejarah dan budaya tentang rawon sebagai kekayaan budaya Indonesia karena penelitian tentang hal ini masih jarang dilakukan.

\section{DAFTAR PUSTAKA}

\section{Anggorodi R. 1984. Ilmu Makanan Ternak Umum. Jakarta.}

Anonim, melalui: <http://manfaatnyasehat.blo gspot.com/2014/01/kandungan-gizi- 
Sri Fajar Ayuningsih, Pelestarian Rawon Nguling Sebagai Nilai Tambah Pada Pengembangan ...

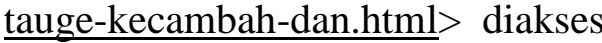
tgl 5 agustus 2015.

Anonim, melalui: http://travel.kompas.com/read/2013/10 /02/0800309/Ragam.Rawon.di.

Kandang.Rawon> diakses tgl 20 Juli 2015.

Anonim. 2006. Pengujian Organoleptik (Evaluasi Sensori) dalam Industri Pangan. Melalui: $<$ http://tekpan.unimus.ac.id/wpcontent/uploads/2013/07/PengujianOrganoleptik-dalam-IndustriPangan.pdf $>$ diakses tgl 5 agustus 2015.

Antara, Nyoman Semadi, dan Wartini, Made. Modul Kuliah Senyawa Aroma Dan Citarasa (Aroma And Flavor Compounds), Tropical Plant Curriculum Project, Udayana University.

Buckle, K.A. R.A. Edward, G.H. Fleet and Wootton, 1987. Ilmu Pangan. Penerjemah H. Purnomo dan Adiono, UI-Press, Jakarta.

Desrosier, N. W. 1969. Teknologi Pengawetan Pangan. Penerjemah: Muchji Mulijohardjo. Penerbit Universitas Indonesia (UI-Press), Jakarta.

Effendi, H. 2003. Telaah Kualitas Air, Kanisius, Yogyakarta.

Emmawati, Aswita. Skripsi. F 31.0853. Pengaruh Kandungan Picung Dalam Bumbu Rawon Terhadap Aktivitas Antimikroba Dalam Sistem Pangan.

Fardias, S. 1998. Kajian Sifat Antimikroba dan Antioksidan Bumbu-bumbu Masakan Tradisional Indonesia dan Peningkatan Fungsinya untuk Menjamin Mutu dan Keamanan Makanan Tradisional.

Frazier, W.C. and P.C. Westhoff, 1977. Food Microbiology. Mc. Graw Hill Book Co. Inc. New York. Guenther, E. (1990). Minyak Atsiri. Jilid IVB. Jakarta: Penerbit Universitas
H. Bunning. 1926. Serat Wulangan OlahOlah Warna-Warni. Yogyakarta: $\mathrm{H}$. Bunning. Diterjemhakan oleh R.Ay. Ng. Sri Kayati Sutarmo dan Dr. Timbul Haryono.

Haryono, Timbul. Serat Centhini sebagai Sumber Informasi Maakanman Tradisional Masa Lampau. Humaniora No. 8 Juni-agustus 1998.

Helabumi, Raditya, melalui: $<$ http://travel.kompas.com/read/2013/1 0/02/0800309/Ragam.Rawon.di.Kand ang.Rawon> diakses tgl 3 juni 2015.

Inskeep, Edward. 1991. Tourism Planning: An Integrated and sustainable Approach. Van Nostrand Reinhold. New York, Inc.

Koswara, Sutrisno. 2009. Pengawet Alami Untuk Produk Dan Bahan Pangan. eBookPangan.com

Labensky and Alan M. Hause. On Cooking: A Textbook of Culinary Fundamentals (Prentice Hall, 1995; $4^{\text {th }}$ ed. 2006)

Lawrie RA. 1991. Meat Science. Ed ke-4. Oxford : Pergamon Pr

Lewlees, Harry T. and Heymann, Hildegarde. 2010. Sensory Evaluation of Food. Prionciples adn Practises. Second Edition. Springer.Indonesia. Hal. 693697

Marsono, dkk., 2005. Centhini Tambangraras Amongraga Jilid I XII. (Yogyakarta: Gajah Mada University Press.

Muchtadi,T.R., dan Sugiyono. 1992. Petujuk Laboratorium Ilmu Pengetahuan Bahan Pangan. Departeme Pendidikan dan Kebudayaan. Direktorat Jenderal Pendidikan Tinggi Pusat Antar Universitas Pangan dan Gizi, Institut Pertanian Bogor.

Muhilal. 1995. Makanan Tradisional Sebagai Sumber Zat Gizi dan Non Gizi dalam Meningkatkan Kesehatan Individu dan Masyarakat. Makalah 115 disampaikan dalam Widyakarya 
Nasional Khasiat Makanan Tradisional. Jakarta, 9-11 Juni 1995.

Munawaroh, Safaatul, \& Handayani, P. A. Jurnal Kompetensi Teknik Vol. 2, No.1, Novemberi 201073 Ekstraksi Minyak Daun Jeruk Purut (Citrus hystrix D.C.) Dengan Pelarut Etanol dan N Heksana. Program Studi Teknik Kimia, Universitas Negeri Semarang primatk@staff.unnes.ac.id

Murdiati, Agnes, dan Amaliah, 2013. Edisi Kedua, Panduan Penyiapan Pangan Sehat Untuk Semua. Penerbit Kencana - Prenadamedia Group.

Murdijati-Gardjito. 2013. Bumbu, Penyedap, dan Penyerta Masakan Indonesia. Gramedia Pustaka Utama, Jakarta.

Owen, Sri. 1980. Indonesian Food and Cookery. Indira Reprints

Palupi, W.D.E. 1986. Pengolahan Daging Pusat Dokumentasi IlmiahNasional. Lembaga. Pengetahuan Indonesia.

Parwata OA. 2008. Isolasi dan uji aktifitas antibakteri minyak atsiri dari rimpang lengkuas (Alpinia galanga). Jurnal Kimia 2(2):100- 104.

Pearson, A.M. dan F.W. Tauber. 1984. Proced Meats. AVI Publishing Company, Inc.Westport, Connecticut.

Rolland P. Carpenter, David H. Lyon, and Terry A. Hasdell. 2000. Guidelines for Sensory Analysis in Food Product Development and Quality Control. Second Edition. Aspen Publisher Maryland.

Rubatzky, V.E. dan M. Yamaguchi, 1998. Sayuran Dunia, Prinsip, Produksi, dan Gizi. Jilid Kedua. Terjemahan Catut Herison. ITB-Press. Bandung.

Santosa, B. 1988. Bawang Putih. Kanisius. Yogyakarta.
Susilantini, Endah. 2014. Kuliner Tradisional Jawa Dalam Serat Centhini. Balai Pelestarian Nilai Budaya Yogyakarta.

Syah, Darul. 2012. Pengantar Teknologi Pangan. IPB Press. 279 - 290 halaman

Syamsir, E., melalui; http://ilmupangan.blogspot.com/2010/ 02/teknik-thawing-yang-aman.html diakses 7 Juli 2015

Tambunan, A.H., 1999. Pengembangan Metoda Pembekuan Vakum Untuk ProdukPangan. Usulan Penelitian Hibah Bersaing Perguruan Tinggi. Institut Pertanian Bogor.

Tjahjadi, C., dkk. 2011. Bahan Pangan dan Dasar-dasar Pengolahan. Universitas Padjadjaran, Jatinangor.

Tranggono dan Sutardi. 1989. Biokimia dan Teknologi Pasca Panen. Proyek Pengembangan Pusat Fasilitas Bersama antar Universitas (Bank Dunia XVII) - PAU Pangan dan Gizi Universitas Gadjah Mada, Yogyakarta.

Wijayanti, P.M., Kirana, A., Indriaswati, T. Jurnal. Biskuit Tauge Sebagai "Healthy Super Food" Berbasis Sumber Daya Lokal.

Winarno, Bondan. Empat Rawon Juara. Jalan sutera, Jumat 28 November 2008.

Winarno, Bondan, 2013. 100 Makanan Tradisioanl Indonesi Mak Nyus (316317). PT Gramedia Pustaka Utama, Jakarta.

Winarno, F.G. 1992. Kimia Pangan dan Gizi. PT. Gramedia Pustaka Utama, Jakarta.

Winarno, F.G. 1993, Makanan Tradisional, Gizi dan Khasiat, Prosiding, Seminar Pengembangan Pangan Tradisional dalam Rangka Penganekaragaman Pangan, Kantor Menteri Negara Urusan Pangan dan Urusan Logistik. 